\title{
GAO report vindicates Teller but critics disagree
}

\section{Berkeley}

Physicist Edward Teller was not alone among weapons scientists in believing that the X-ray laser could become the backbone of the Strategic Defense Initiative (SDI), nor is there a scientific consensus that he misled government officials, according to a long-awaited report by the US General Accounting Office (GAO)*

But critics of the report say its findings are inaccurate and blame politics for clouding its conclusions.

The report was requested by US Representative George Brown after Roy Woodruff, a physicist at Lawrence Livermore National Laboratory (LLNL), accused Teller of misleading government policy-makers. Woodruff also claimed that the former LLNL director, Roger Batzel, would not allow him to present his criticisms in writing. Woodruff resigned as associate director for defence systems in October 1985, saying he would not be responsible for fulfilling Teller's promises. Later he filed a personnel grievance with the University of California (UC), which oversees the laboratory, for what he felt were reprisals, based on his opposition to Teller. He won his grievance, and was reinstated as associate director for weapons verification research in December 1987 (see Nature 329, 751; 1987 and 330, 594; 1987).

Among its findings, the GAO report states that the "official channel" at LLNL had made statements about the X-ray laser similar to those made by Teller and

\section{UK record network}

\section{London}

BRITAIN urgently needs a national network of biological records to bring cohesion to the present inefficient and ramshackle system, according to a committee of the Linnean Society, which issued its report two weeks ago. The chairman of the committee, Professor Sam Berry, president of the British Ecological Society, urged the need of a national system so that planners can make informed decisions on land use, especially with the prospect of changes in the countryside as agricultural land is taken out of production and as cities exert pressure on surrounding green belt areas.

The committee makes four main recommendations: a national coordinating commission; a national network of biological records centres linking and supporting local centres; a national collative and interpretative unit; and a central data store.

The total cost of the proposals would be between $£ 300,000$ and $£ 1$ million.

Christine McGourty challenged by Woodruff. And, while Woodruff was asked not to send his written objections to Teller's statements to government officials, the report notes that he did present those views verbally to a number of top government officials, including presidential science adviser George Keyworth and chief arms control negotiator Paul Nitze. The report characterizes Keyworth as a knowledgeable physicist who knows Teller as a "technical optimist", and did not need clarification of Teller's views. It also suggests that Teller was not alone in his views, but that scientific opinion about the feasibility of the $\mathrm{X}$ ray laser covered the whole spectrum.

Current LLNL director John Nuckolls, not available for comment on the report, said through a laboratory spokeswoman that it was "the best that could be expected, given the complexity of the situation". Woodruff also gives the report a lukewarm review, calling it "marginally acceptable". By documenting statements and letters by Batzel, Teller and Teller's protégé Lowell Wood, he says the report confirms "that everything I ever said is absolutely correct". Woodruff dismisses the report's conclusions as not supported by the facts, and contends that the report was "deliberately made confusing, because it is a hot political issue". Nevertheless, he says the report now allows him to discuss the real reason he resigned, which was the previously classified plan for a multiple-beam X-ray laser, known as Super Excalibur, characterized by Woodruff as a last-ditch effort to design a system that would make SDI possible. The report cites a letter from Teller to Nitze that describes Super Excalibur as "a single X-ray laser module the size of an executive desk which ... could potentially shoot down the entire Soviet landbased missile force, if it were to be launched into the module's field of view". But that, says Woodruff, is like promoting the atom bomb before scientists had any idea of how to split the atom.

Woodruff says the GAO report supports his complaint that Super Excalibur was no more than "pie in the sky", a weapon on paper only, that Teller was promoting with no supporting data, in the hope of influencing the Geneva arms reduction talks. The report quotes a December 1984 letter from Teller to national security adviser Robert McFarlane, in which he said that Super Excalibur "might be accomplished in principle within a few years", as well as a conflicting statement by Batzel to the House Armed Services Committee in February 1986 that "there are no data at this stage of the game" that would support the feasibility of Super Excalibur.

The report also addresses the controversy over Excalibur, a more modest proposal for a single-beam X-ray laser which would not be able to shoot down an incoming missile barrage, but rather whose major application would be as an anti-SDI weapon. The report notes Woodruff's objections to Teller's assertion that Excalibur was ready to enter engineering phase. The brightness of the laser had not been confirmed, according to Woodruff, and critical scaling experiments remained to be done. The report notes that George Miller, who succeeded Woodruff as associate director for defence systems, agrees with Woodruff that Excalibur was not ready for engineering then, nor is it today.

Woodruff, while satisfied that the facts have been aired on his disagreements with Teller, says the real issue is the role of the University of California as overseer of the laboratory in such a dispute. Woodruff says he is still living under the stigma of being the "whistle-blower", and fears he may be forced out of his new job. He complains that UC has not defended his academic freedom to balance Teller's scientific claims, and that UC president David Gardner has never spoken to him nor agreed to investigate his complaints.

The university, for its part, characterizes Woodruff's employment complaints as a personnel issue, to be handled internally by the laboratory. Gardner has pointed out that Teller, as a retired LLNL director, was not an official spokesman and was free to express his personal views in writing, while Woodruff, as an associate director, would, if he commented in writing, be seen as giving the official stamp of approval to a scientific opinion.

The California legislature included in this year's UC budget a request that the university increase its oversight of the Livermore and Los Alamos weapons laboratories, with one specific goal being to ensure that research is technically sound and not misrepresented to government officials, and that dissenting views be presented.

At their 15 July meeting, the UC regents chose not to adopt the budget request, but rather to initiate a study to evaluate the need for greater oversight. According to a UC spokesman, an increase in university oversight is unlikely, as Gardner believes that it would conflict with the jobs of the laboratory directors.

In a statement to the regents, Gardner reiterated his philosophy that management of the laboratories should parallel the management of individual UC campuses, with relative autonomy given to the directors, as it is to the chancellor of each campus. Marcia Barinaga

* Strategic Defense Initiative Program: Accuracy of Statements Concerning DOE's X-Ray Laser Research Program. US General Accounting Office Report, June 1988. 